\title{
Misconceptions in Projectile Motion and Conceptual Changes via Geogebra Applications
}

\author{
Ferhat Aslan, (MA) \\ Erciyes University, Turkey \\ Ugur Buyuk, (Prof. Dr.) \\ Erciyes University, Turkey
}

\begin{abstract}
:
The purpose of this work is to examine the issue of pre-service science teachers' (PSST) Geogebra applications on misconceptions about projectile motion (PM) and the permanence of learning concepts. In this study, quantitative research method was used as scientific research method, and semi-experimental design with pre-test, post-test control group was used as a pattern. The accessible population of this study is PSST who study in a university located in Kayseri, Turkey in the 2019-2020 academic year. Sample of the study included 36 freshman PSST, studying at the university level in Kayseri. 18 of the participants are experimental-group (EG) and 18 of them are control-group (CG). Both groups learned the subject of projectile motion (PM) together in the classroom. In addition to the traditional teaching method, the EG participated eight-week in the Geogebra course based on the conceptual change model and prepared physics simulations with Geogebra. "Conceptual Questions on Projectile Motion" was used as a data collection tool and the data were analyzed by means of statistics (t-test) based on the difference between averages. The results revealed that both the post-test's and permanence test's mean scores of the EG PSST were significantly higher than the mean score of the CG PSST (post-test: $t=2.525 ; \mathrm{p}<.05$ ) (permanence test: $\mathrm{t}=5.466 ; \mathrm{p}<.05)$. Furthermore, in this study, many misconceptions about the PM were identified.
\end{abstract}

Key Words: (Science Education, Projectile Motion, Conceptual Change, Geogebra Applications,)

\section{Introduction:}

The basic premise of constructivism is that knowledge is constructed "from physical interaction with objects in the world" (Fosnot \& Perry, 1996). Thus, it is integral for students to actively engage with the material, manipulate objects and construct new works and then that they can fully interpret the issue. Although real physical interaction is not possible in virtual environments, the virtual environment can also lead to a lifelike experience with facts and material and can significantly aid the learning process. The proposals for defining constructivist learning views (Fox, 2001) are as follows:

1. Learning is a dynamic, continuous, active process.

2. Knowledge is not inherent or passively assimilated. It is structured.

3. Cognitive knowledge, neither discovered, nor invented.

4. All knowledge is unique and personal.

5. All knowledge is socially structured.

6. Learning is the process of understanding how the universe works. 
7. To solve students' meaningful, open-ended, challenging problems effective learning is needed.

The expectation of knowledge in the area of science education has gone beyond the actual knowledge. Mindful learning which structured via scientific experiences is more significant than the ability to quickly solved many types of multiple-choice problems. Nowadays, recall of knowledge is perceived as inadequate in science education. Students should relate their old knowledge to new knowledge for meaningful learning. Knowledge that is incompatible with scientific facts may have been acquired from informal sources of knowledge, some of their own experiences in the physical and social world, misplaced metaphors embedded in the language, teaching plan (Klammer, 1998) and textbooks (Cho, Kahle, \& Nordland, 1985). In addition, teaching may inadvertently promote these concepts and even create these misconceptions during teaching.

Students usually come to science class with their established misconceptions. These misconceptions must be taken into account by science teachers in order to plan and teach meaningful and efficient lessons. Science teachers require to recognize the students' misconceptions and change their teaching style according to misconceptions of students'.

As a result of a study about students' misconceptions or "Alternative Concept Movement" research, the following seven propositions about misconceptions are mostly accepted (Millar, 1989).

1. Students get into science class with deep-rooted knowledge about natural phenomena,

2. Alternative concepts of students may vary according to ability, nationality, gender and age,

3. Traditional teaching strategies are not enough for alternative concepts of students to change,

4. Alternative concepts of students are frequently similar to the explanations of natural phenomena presented by former generations of scientists.

5. The origins of students' alternative understanding are personal experiences, culture, perceptual experience, their language and school.

6. Teachers also have misconceptions like their students,

7. Alternative concepts of students' dispute with the knowledge taught in formal education.

Some studies (Clement, 1982; Gilbert \& Watts, 1983; Minstrell, 1984) have shown that many students have beliefs that are somewhat or entirely different from accepted scientific views. Students' misconceptions create obstacles to meaningful learning in science. Consequently, students' misconceptions must be revealed and eliminated to provide meaningful learning and a passing on general scientific concepts.

In the last 40 years, an active research literature on students' conceptual understanding in science has been constituted. These researches provided science education community with detailed knowledge about students' conceptions of natural phenomena in a broad range of science topics (mechanics, optics, electricity, energy, particle physics, heat and temperature, astronomy and many other fields) (Duit, 1993). Constructivist learning approach has been the strongest source of motivation for research on students' understanding (and also teachers') (Duit, 1993). It forms students' understanding of natural phenomena with all their experiences, both in and out of school.

In the first studies on students' concepts, educational scientists considered students' concepts according to the subject and separately from other aspects of learning such as metacognition (Duit \& Treagust, 2003). Many studies (Driver \& Erickson, 1983; Driver, Guesne, \& Tiberghien, 1985; Driver, Squires, Rushworth, \& Wood-Robinson, 1994; Duit, Goldberg \& Niedderer, 1992; McDermott, 1984; Novak, 1987; Osborne \& Freyberg, 1985) showed that students do not enter classes without prior knowledge of the natural phenomena to be taught. In 
fact, students have deep-rooted concepts and ideas which are incompatible with contemporary scientific views and cannot be quenched by traditional teaching.

Since the 1970s, studies have been conducted investigating students' understanding of mechanics (Duit, 1993). A number of these studies have been reviewed in order to understand students' conceptual understanding of the concepts of the force and motion unit and the subject of the PM (Bayraktar, 2009; Clement, 1982; Clement, 1983; Dilber, Karaman, \& Düzgün, 2009; Driver, Rushworth, Squires, \& Wood-Robinson, 1994; Halloun \& Hestenes, 1985a; Halloun \& Hestenes, 1985b; Jimoyiannis \& Komis, 2001; Klammer, 1998; Klein, Gröber, Kuhn, \& Müller, 2014; McCloskey, 1983a; McCloskey, 1983b; McCloskey, Caramazza , \& Green, 1980; Minstrell, 1982; Prescott, 2004; Prescott \& Mitchelmore, 2005; Sadanand \& Kess, 1990; Tao, 1997; Tao \& Gunstone, 1999; Trowbridge \& McDermott, 1980; Whitaker, 1983). Some of the misconceptions presented in these studies and their scientific equivalents are shown in Table 1 with references and more given Appendix-1.

\begin{tabular}{|c|c|c|}
\hline Misconception & Scientific equivalent & Reference \\
\hline $\begin{array}{l}\text { An object released from constant } \\
\text { 1. horizontal velocity follows a linear } \\
\text { path. }\end{array}$ & $\begin{array}{l}\text { For an observer on the } \\
\text { ground, the orbit of the object } \\
\text { will be parabolic. }\end{array}$ & $\begin{array}{lr}\text { (Hallon } & \& \\
\text { Hestenes, } & 1985 b ; \\
\text { McCloskey, 1983b) }\end{array}$ \\
\hline $\begin{array}{l}\text { An object falls back from the position } \\
\text { 2. where it was released with horizontal } \\
\text { constant initial velocity. }\end{array}$ & $\begin{array}{l}\text { For an observer on the } \\
\text { ground, the orbit of the object } \\
\text { will be parabolic. }\end{array}$ & $\begin{array}{l}\text { (Hallon } \quad \& \\
\text { Hestenes, 1985b; } \\
\text { McCloskey, } \\
\text { 1983b) }\end{array}$ \\
\hline $\begin{array}{l}\text { 3o force is applied to an object } \\
\text { released from a moving carrier. }\end{array}$ & $\begin{array}{l}\text { A force is applied by the } \\
\text { gravitational field of the } \\
\text { ground to an object making a } \\
\text { horizontal PM. }\end{array}$ & $\begin{array}{lr}\text { (Hallon } & \& \\
\text { Hestenes, } & 1985 b ; \\
\text { McCloskey, 1983b) }\end{array}$ \\
\hline $\begin{array}{l}\text { From the same height, a released } \\
\text { object falls before the object at a } \\
\text { horizontal constant velocity because } \\
\text { 4. the released object takes a shorter } \\
\text { path. Or the thrown object falls first } \\
\text { because it has a greater velocity than } \\
\text { the object released. }\end{array}$ & $\begin{array}{l}\text { An object that is released } \\
\text { from the same height and the } \\
\text { other thrown with a horizontal } \\
\text { constant velocity hit to the } \\
\text { ground simultaneously. }\end{array}$ & $\begin{array}{l}\text { (Dilber et al., 2009; } \\
\text { Jimoyiannis \& } \\
\text { Komis, 2001; } \\
\text { Prescott } \\
\text { \&Mitchelmore, } \\
\text { 2005; } \\
\text { Whitaker; 1983) }\end{array}$ \\
\hline
\end{tabular}

The final velocity of an object which

5. released to free fall depends on the force of gravity.

A ball with greater mass will have a

6. greater velocity when released into free fall.

7. The larger the mass, the greater the acceleration in free fall.

The higher the ball of two balls of

8. different heights, the acceleration is greater because it moves more.
The final velocity of objects released to free fall depends on the height at which the objects are released and the gravitational acceleration.

The acceleration of free- (Jimoyiannis \& falling objects is the Komis, 2001) gravitational acceleration of (Jimoyiannis \& the planet.
(Dilber et al., 2009)

(Jimoyiannis \&

Komis, 2001)

Komis, 2001)

Table 1. Misconceptions about projectile motion and the scientific equivalents of them.

Knowing that students bring strong misconceptions into science classes (Dekkers \& Thijs, 1998; Duit \& Treagust, 2003; McDermott, 1991) that are difficult to quench through traditional teaching, researchers have been looking for theoretical frameworks to explain how students reconstruct their current concepts. Researchers from different area of study (e.g: science education 
and educational psychology) have proposed different theoretical frameworks to explain the nature of students' misconceptions and how they replace them with scientifically accepted concepts.

Posner, Strike, Hewson, and Gertzog (1982) developed the Conceptual Change Model to provision explanations on how a student's existing understanding change when faced with recent understanding. The Conceptual Change Model has a common practice in the science education community since its development (Duit \& Treagust, 2003). By the vision of Conceptual Change Model, a new understanding can be incorporated into the cognitive structure in two ways: if the student knows rare about the recent shown concept or if the recent concept can be adapted with the present conceptual structure new concept can be merged with the present concept. This process called as "assimilation" by Posner et al. (1982). By Hewson (1981) it is called as "conceptual capture". On the other hand, there is a possibility that students have alternative understanding of what they will learn that may conflict with new knowledge. In lodge to accept new knowledge, the students must reconstruct their existing understanding. This process has been named "conceptual change" by Hewson (1981), "accommodation" by Posner et al. (1982). The main focus of the Conceptual Change Model which is presented by Posner et al. (1982), is to clarify how accommodation takes place. There are four conditions that must be met for conceptual change to occur:

1. The student is not satisfied with the current understanding,

2. Finding that the new understanding is understandable,

3. The learner thinks that the new understanding is reasonable,

4. The learner should find the new understanding efficient and the new understanding should lead to new ones (Posner et al., 1982).

The learning view presented in Conceptual Change Model provides an explanation of how students can change their existing knowledge structures in a subject area. Different theoretical frameworks have been proposed to explain the nature of the change in students' current cognitive structure.

The proposed theoretical frameworks for explaining the improvement in students' understanding require that: reach an improvement in the current conceptual structure, students collocate existing concepts against the new concept, recognize existing and new concepts, and the relevant connection every day, integrate and evaluate. Planning lessons compatible with technology can facilitate conceptual change. In a technology-based lesson which is planned according to the conceptual change model, misconceptions can be eliminated by bringing students face to face with their misconceptions.

GeoGebra, developed in 2001 by Marcus Hohenwarter and Yves Kreis, is a free dynamic geometry software developed to teach and learn mathematics at primary, high school and university level (Hohenwarter \& Preiner, 2007). Although the use of this software in the field of mathematics is quite common, it is very rare in science education (Erb, Wilhelm, \& Kuhn, 2015; Hofmann, Klar, \& von Aufschnaiter, 2012; Kerle, 2013; Solvang \& Haglund, 2018; Völker, 2015; Walsh, 2017). However, some of them are limited to the use of graphics, figures and animations rather than the physics teaching process (Hofmann, Klar, \& von Aufschnaiter, 2012; Völker, 2015). Moreover, Geogebra, where many applications can be made in terms of graphics and visuality, can also make up the ground for the elimination of misconceptions with the experience it will provide to students. Solvang and Haglund (2018) emphasized the importance of using digital tools in education for high school physics education in Sweden. Solvang and Haglund (2018) stated that they investigated the possibilities of using GeoGebra, which is very popular in mathematics education, in the teaching of physics subjects, and discovered the cognitive learning processes of students during their interactions with the software. They observed that there was a "high level of interaction" between students and Geogebra applications and that students came to different levels of understanding the subject of friction (Solvang \& Haglund, 2018). 
It is more common to use physics simulations where it can only change variables, and sometimes even not. However, Geogebra allows its users to manipulate it. Walsh (2017) states that when creating physics simulations in GeoGebra, Walsh can usually understand a subject or phenomenon more deeply. Furthermore, teaching a certain concept after many years, he can better understand the concept after figuring out how to simulate it with Geogebra.

Many studies (Jimoyiannis \& Komis, 2001; Klein, et al.; 2014; Whitaker, 1983) have been conducted on the conceptual difficulties that students' mental models experience with regard to the phenomena of the PM. The motivation behind this study is to make up for the lack of studies on physical phenomena related to misconceptions of PM. Just a few studies have tried to change students' misconceptions about PM (Dilber et al., 2009; Gunstone, Gray \& Searle, 1992; Thijs, 1992). In this study, it is aimed to define the misconceptions of PSST regarding the concepts of the PM and to examine the effectiveness of Geogebra applications based on conceptual change conditions on their understanding of the concepts of PM on traditionally designed physics education. In addition, in this study, it is aimed to reveal the misconceptions that PSST had in explaining the physical phenomena underlying the PM. For this purpose, in accordance with the nature of the study, in order to eliminate many misconceptions and to realize conceptual changes, lesson plans were prepared in Geogebra. Relatedly, an eight-week Geogebra course practice was made with PSST. Consequently, in this study, the misconceptions of PSST about PM were determined and Geogebra applications were used to overcome them by applying the conceptual change model.

\section{METHOD}

\section{Research Model}

The quantitative research method was applied in this study, in which the effect of the teaching carried out with Geogebra applications in the Physics lesson of PSST on the misconceptions of the "Force and Motion" unit of PSST on the subject of " Projectile Motion " was used. According to Fraenkel and Wallen (2006), since experimental research is the best way to establish cause-effect relationship, quasi-experimental design with control group was used to pre-test, post-test and permanence test to discover the effect of learning PM with Geogebra in the experimental group.

\section{Population and Sample}

The accessible population in this study is the PSST studying science education in Kayseri (Turkey). The sample of the study consists of 36 PSST, 18 in the EG and 18 in the CG, studying as a freshman in a university in Kayseri. The sample of the study was determined by the convenience sampling method.

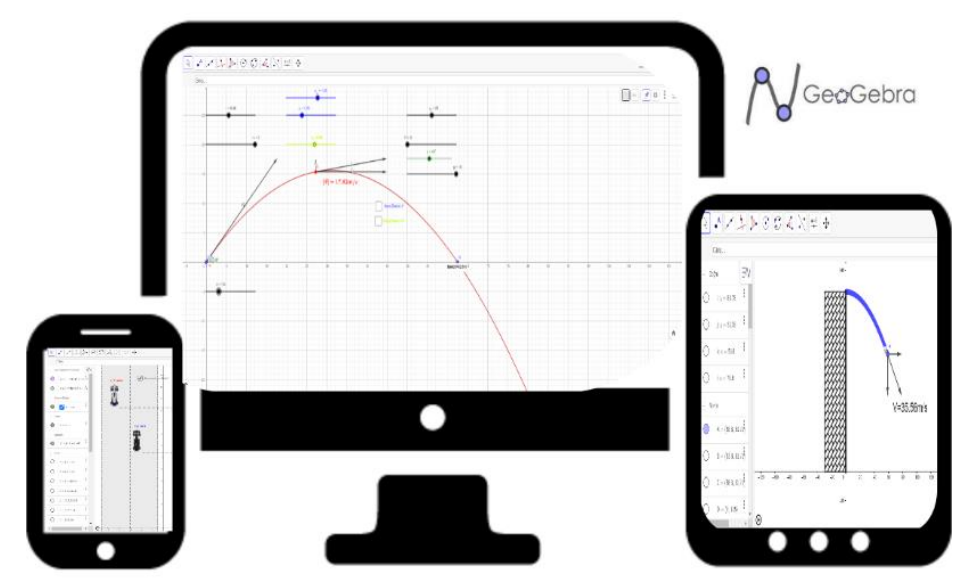

Figure 1. A few examples of the experimental group's Geogebra studies 
Researchers choose convenience sampling; due to time, money and some limitations, the researcher determines the sample from easily accessible and practicable communities (Büyüköztürk, 2012). In this study, researchers included participants whom they could easily reach for logistical reasons. 36 students in the EG and CG took physics lessons together in the same class. In addition to these lessons, 18 students in the EG took an eight-week-long 16-hour course, practice using Geogebra in the computer laboratory, and at the end of this practice, they prepared simulations and animations on the subject of the PM. In Figure 1, some examples of physics simulations made by PSST in Geogebra course practice applied within the scope of this research are given.

\section{Data Collection Tools}

The "Conceptual Questions of Projectile Motion" (CQPM) scale consisting of seven openended question was used as a data collection tool in this study. This scale; was developed by Piten, Rakkapao, and Prasitpong (2017), it was translated into Turkish by the researchers and it was checked by taking the opinions of three experts (English, Physics and Turkish Language and Literature teachers). Seven open-ended questions with CQPM discuss the main ideas of the PM; velocity, acceleration and force $(\mathrm{Q} 1, \mathrm{Q} 2, \mathrm{Q} 5)$, flight times $(\mathrm{Q} 2)$, path $(\mathrm{Q} 3, \mathrm{Q} 4, \mathrm{Q} 7)$, peak point, range and complementary angles (Q6). While Piten, et al. (2017) developed the questions, the consistency between an item and its behavioral goals was evaluated by eight physicists using the "item-goal fit form".

\section{Data Collection and Analysis}

SPSS 22.00 package program was used for the analysis of the data obtained in a period of three months. The obtained findings were evaluated at $95 \%$ confidence interval and 5\% significance level. The minimum score that can be obtained from CQPM is null, the maximum score is 100 . The detailed scoring made by the researcher for CQPM was checked by an expert in the field of physics education and found appropriate. Data collection process and applications are shown in Figure 2.

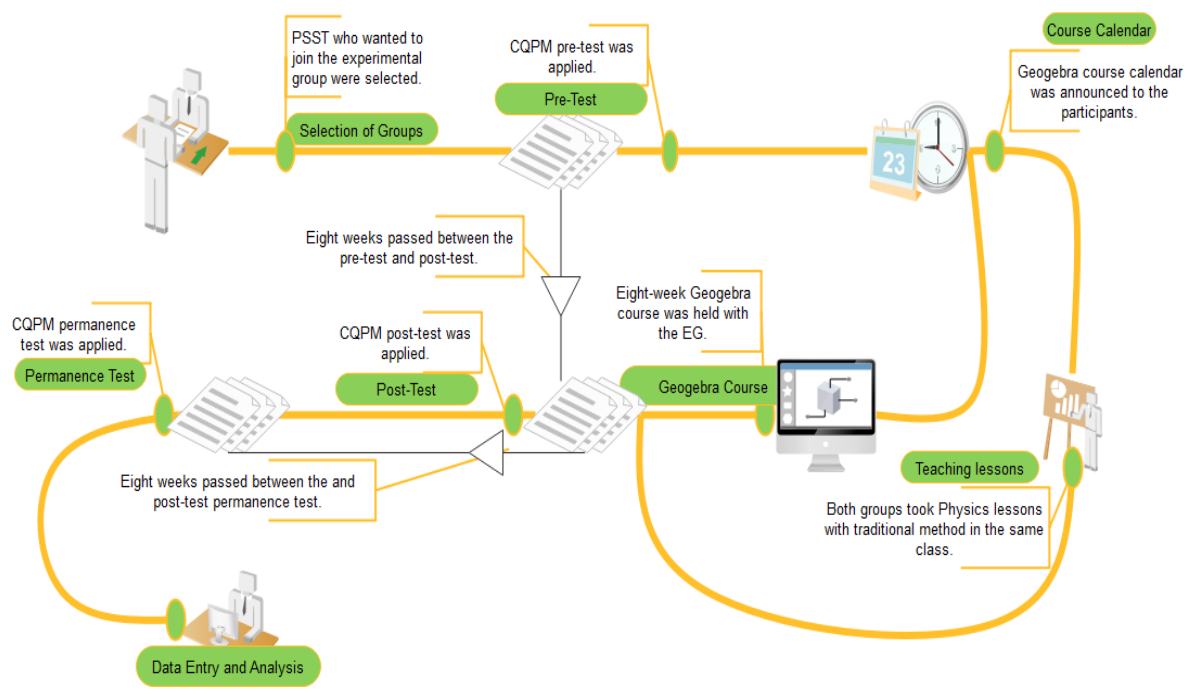

Figure 2. Flowchart diagram of data collection process and courses.

In descriptive statistics, the mean, median, mod, minimum and maximum test scores, standard deviation, skewness and kurtosis values of the pre-test, post-test and permanence test scores of the dependent variables were computed for both the EG and CG. In order to check whether there is a statistical difference between the groups, independent samples t-test was conducted as inferential statistics. All the assumptions of the tests were checked before testing. 


\section{FINDINGS}

\section{Descriptive and Inferential Statistics Results of Experimental Group and Control Group}

In the study, t-test was applied to determine the effects of Geogebra applications on the misconceptions of PSST in physics lesson. The assumptions discussed in Pallant (2011) were checked before applying the independent samples t-test. These assumptions, normality and homogeneity of variances were checked for all test scores. The results of the descriptive analysis are included in Table 2-3. The normality of the data was evaluated by Kolmogorov-Simirnov and Shapiro-Wilk statistics and kurtosis, skewness, mod, median and mean values.

\begin{tabular}{llllrll}
\hline Group & Test & Skewness & Kurtosis & $\overline{\boldsymbol{X}}$ & Median & Mod \\
\hline & Pre-test & .669 & .202 & 26.72 & 24.50 & 19.00 \\
0 & Post-test & .309 & -.930 & 49.58 & 48.50 & 32.00 \\
& Permanence & .746 & -.158 & 30.69 & 28.00 & 16.50 \\
\hline & Pre-test & .153 & -.882 & 27.38 & 27.50 & 16.00 \\
0 & Post-test & -.086 & -1.160 & 17.91 & 19.00 & 10.50 \\
\hline & Permanence & -.120 & -.374 & 14.33 & 15.00 & 15.00 \\
\hline
\end{tabular}

Table 2. Descriptive statistics values for the test scores of the groups

On the Kolmogorov-Simirnov, Shapiro-Wilk tests, the significance values of the pre-test PSST CQPM pre-test, post-test and permanence test results were greater than .05, and the kurtosis and skewness values were lower than 1 , which indicates that the data showed normal distribution (p>. 05). As can be seen from Table 3, the kurtosis value of the post-test of the CG is slightly higher than -1 (-1.160) and the Kolmogorov-Smirnov significance value of the permanence test of the EG is less than .05 ( $\mathrm{p}=0.039)$.

\begin{tabular}{|c|c|c|c|c|c|c|c|}
\hline \multirow[t]{2}{*}{ Group } & \multirow[t]{2}{*}{ Test } & \multicolumn{3}{|c|}{ Kolmogorov-Smirnov } & \multicolumn{2}{|c|}{ Shapiro-Wilk } & \multirow[b]{2}{*}{$\mathbf{p}$} \\
\hline & & Statistic & df & $\mathbf{p}$ & Statistic & df & \\
\hline \multirow[b]{3}{*}{ U } & Pre-test & .120 & 18 & $.200^{*}$ & .961 & 18 & $.629^{*}$ \\
\hline & Post-test & .118 & 18 & $.200^{*}$ & .959 & 18 & $.591^{*}$ \\
\hline & Permanence & .208 & 18 & .039 & .919 & 18 & $.124^{*}$ \\
\hline \multirow[b]{3}{*}{$\circlearrowright$} & Pre-test & .112 & 18 & $.200^{*}$ & .974 & 18 & $.862^{*}$ \\
\hline & Post-test & .113 & 18 & $.200^{*}$ & .954 & 18 & $.489^{*}$ \\
\hline & Permanence & .141 & 18 & $.200^{*}$ & .959 & 18 & $.582^{*}$ \\
\hline
\end{tabular}

Table 3. Kolmogorov-Smirnov and Shapiro-Wilk statistics for the test scores of the groups

On the Kolmogorov-Simirnov, Shapiro-Wilk tests, the significance values of the pre-test PSST CQPM pre-test, post-test and permanence test results were greater than .05, and the kurtosis and skewness values were lower than 1, which indicates that the data showed normal distribution (p>. 05). As can be seen from Table 3, the kurtosis value of the post-test of the CG is slightly higher than -1 (-1.160) and the Kolmogorov-Smirnov significance value of the permanence test of the EG is less than .05 ( $\mathrm{p}=0.039)$. On the other hand, it was concluded that a normal distribution was shown by looking at the other results in the relevant tests. Based on these results, it was decided that the t-test results of the groups could be compared. The t-test results for the groups are given in Table 4. 


\begin{tabular}{|c|c|c|c|c|c|c|c|}
\hline Test & Group & $\mathbf{N}$ & $\bar{X}$ & Sd & df & $\mathbf{t}$ & $\mathbf{p}$ \\
\hline \multirow{2}{*}{$\begin{array}{l}\tilde{D} \\
\stackrel{d}{d} \\
\stackrel{d}{d}\end{array}$} & $\mathrm{EG}$ & 18 & 26.722 & 10.814 & \multirow{2}{*}{-31.108} & \multirow{2}{*}{-.154} & \multirow{2}{*}{.878} \\
\hline & $\mathrm{CG}$ & 18 & 27.388 & 14.817 & & & \\
\hline \multirow{2}{*}{ 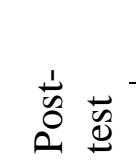 } & $\mathrm{EG}$ & 18 & 49.583 & 15.718 & \multirow{2}{*}{34} & \multirow{2}{*}{7.806} & \multirow{2}{*}{$.000^{*}$} \\
\hline & $\mathrm{CG}$ & 18 & 17.916 & 7.011 & & & \\
\hline \multirow{2}{*}{ 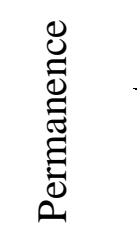 } & $\mathrm{EG}$ & 18 & 30.694 & 11.582 & \multirow[b]{2}{*}{34} & \multirow[b]{2}{*}{5.466} & \multirow[b]{2}{*}{$.000^{*}$} \\
\hline & $\mathrm{CG}$ & 18 & 14.333 & 5.207 & & & \\
\hline
\end{tabular}

Table 4. $t$-test results for test scores of the groups pre-test, post-test and permanence

In order to check whether there is a significant difference between the misconceptions of the groups in terms of PM, the comparison of the CQPM pre-test, post-test and permanence test scores was performed by independent samples t-test. As can be seen from Table 4, the analysis results show that there is no statistically significant difference between the pre-test averages of the groups (pre-test: $\mathrm{t}=-.154 ; \mathrm{p}>.05)$, there is a statistically significant difference in terms of posttest and permanence test. (post-test: $\mathrm{t}=2.525 ; \mathrm{p}<.05$ ) shows (permanence test: $\mathrm{t}=5.466 ; \mathrm{p}<.05$ ).

\section{Misconceptions Detected on the Conceptual Questions of Projectile Motion Scale}

In this section, the answers given by PSST to CQPM are presented as a percentage on the basis of questions. The pre-test, post-test and permanence test results of the answers given by the PSST were evaluated separately as a percentage and EG and CG and are given in Table 5. In Figure 3 , some of the answers containing misconceptions detected in this study are given. In addition, the summary of the misconceptions detected in this study, their scientific equivalent and their references in the literature are presented in Appendix-2.

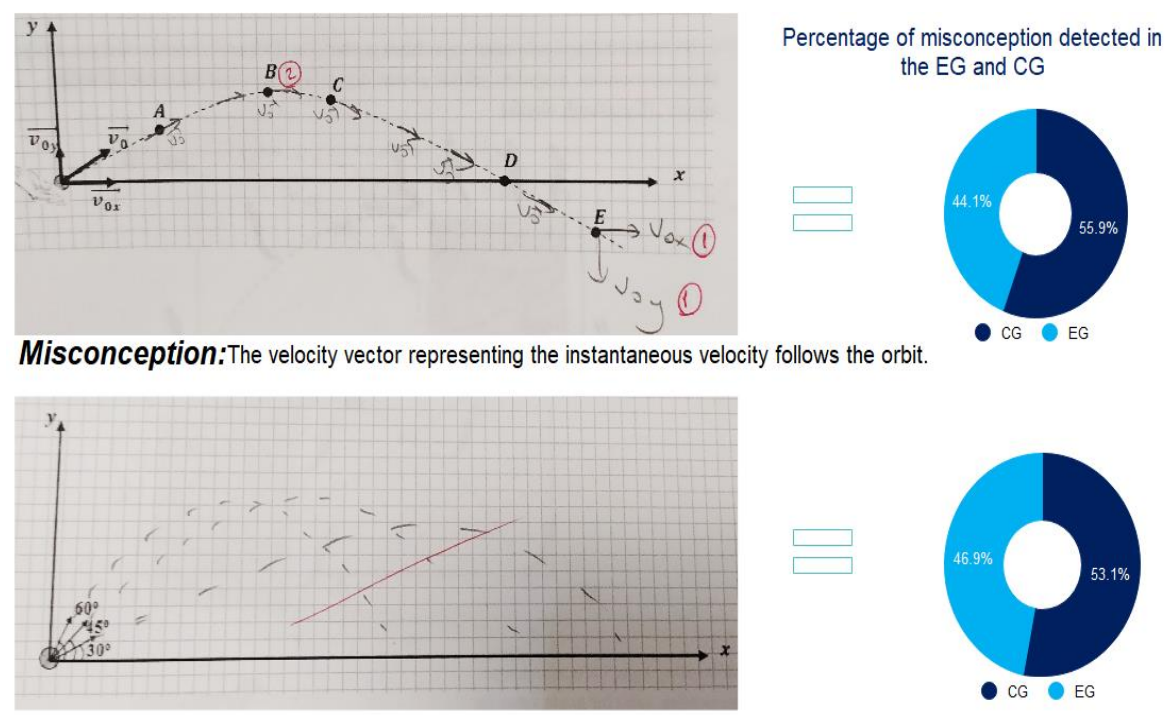

Misconception: The object thrown at a smaller angle will travel a longer distance horizontally.

Figure 3. Examples of misconceptions detected in CQPM. 


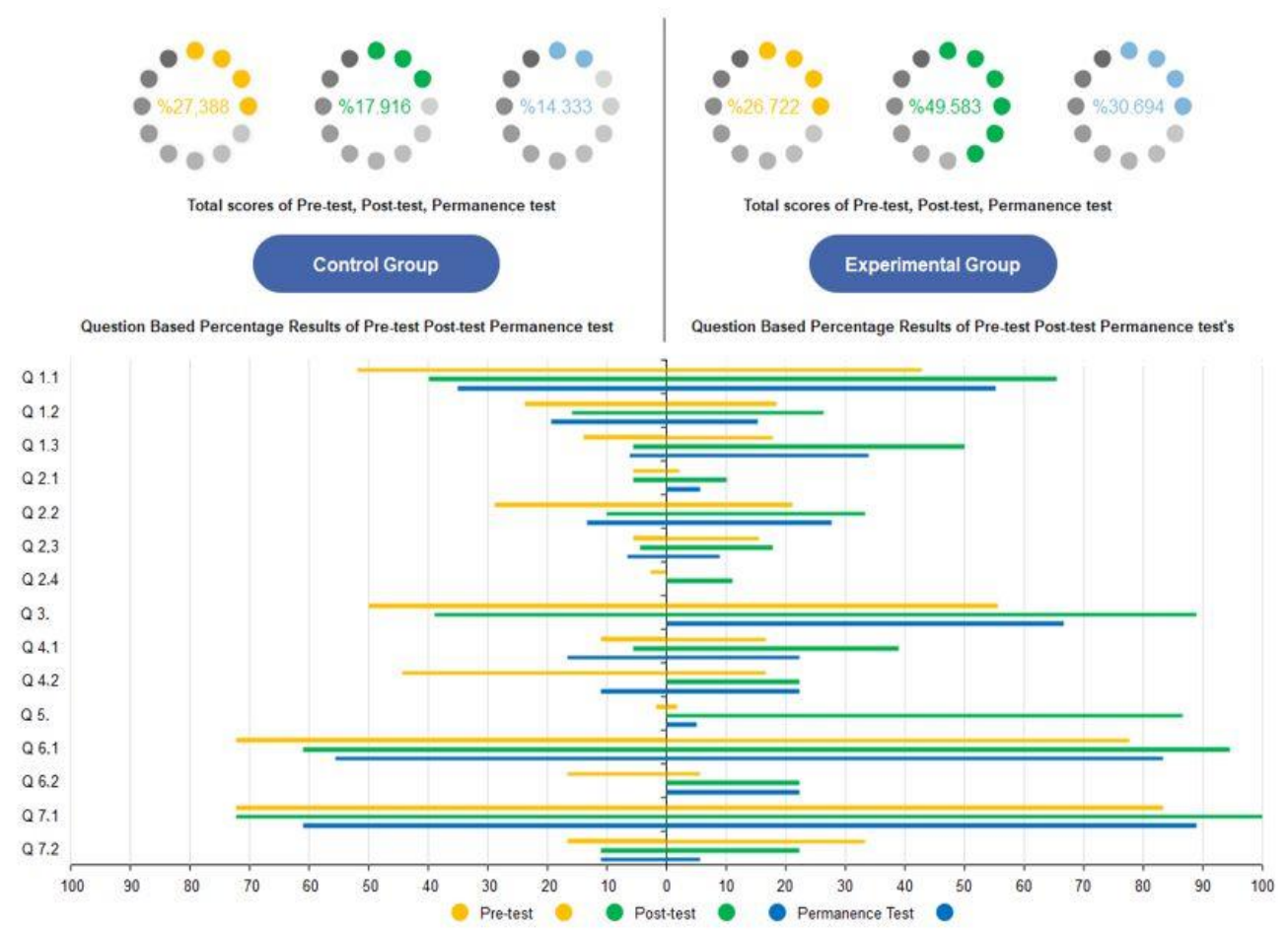

Table 5. Percentage results of the EG and CG PSST on the basis of CQPM total and questions

\section{Conclusion and Discussion}

The main purpose of this study is to investigate the effect and permanence of Geogebra applications on the detection and elimination of misconceptions of PSST about physics lesson PM. For this purpose, before comparing the experimental and control groups, independent samples ttest was used to determine whether the groups showed a significant difference in terms of misconception levels. There was no statistically significant difference in the CQPM pre-test results: $\mathrm{t}=-.154 ; \mathrm{p}>.05$ (Table 4 ). Accordingly, the groups' misconceptions before the Geogebra course are at the same level.

It is seen that there is a significant difference between the EG and the CG in terms of the mean CQPM post-test results: $t=7.806 ; \mathrm{p}<.05$ (Table 4). Thus, at the end of the Geogebra course in the EG, it was determined that the Geogebra applications in the physics lesson positively affected the misconceptions of PSST about the subject of the PM. Moreover, when we look at the pre-test and post-test averages of the PSST studying in the CG (Table 4), an increase of misconceptions observed. This might be resulted from the teaching plan and method, as reported by Klammer (1998) and Millar (1989). The traditional method supported the students' misconceptions and could not realize the conceptual change. While the PSST in the EG explained the physical phenomena, they encountered in the Geogebra course, they made many interactions with the PM while designing the simulation in Geogebra and discovered the scientific reality behind the PM subject. As Posner et al. (1982) mentioned, the EG interacting with the physical phenomenon with Geogebra was not satisfied with the existing understanding, found that the new understanding was understandable, thought it was reasonable, found it efficient, and the new understanding they acquired led to different new understandings. These are the necessary steps for conceptual change to occur. Furthermore, when the permanence test scores of the groups are examined, it is seen that the applied independent samples t-test is in favor of the EG: $t=5.466 ; p$ $<.05$ (Table 4). This result proves the effectiveness of simulations prepared with Geogebra applications in conceptual change.

Each of the question in CQPM tests one or a few misconceptions about PM in physics. The percentage of correct answers to these questions by the groups are given in Table 5. When Table 5 is examined, it is seen that the EG is successful in terms of questions compared to the CG. The 
misconceptions of the PSST in the EG about speed, acceleration and force decreased (Q1, Q2, Q5 test these misconceptions). Especially if we look at the percentage of Q5, it is seen that it increased from $1.66 \%$ to $86.6 \%$. In other words, the misconception of PSST that "The direction of acceleration is the same as the direction of movement" (Tao, 1997, Tao \& Gunstone, 1999) has been largely eliminated. When the permanence test results of the same question are examined, it is seen that the gains obtained from the post-test are mostly lost, although there is a numerical increase compared to the pre-test (5.55\%). Woods and Thorley (1993) stated that students turned to misconceptions even after "strong" teaching. Moreover, they stated that it is difficult to help a student gain a deep and strong understanding when analyzing case studies for students' understanding before and during and about two months after teaching. In the later interviews about the subjects that the students were very successful during and after the teaching of the lesson, it was revealed that the students returned to their previous "alternative concepts", in some cases, they could remember the "correct answer" but could not verify or in some cases their answers were seriously misconfigured. The first part of Q7 in CQPM is choosing the path the ball will follow (Figure 4). The percentage of those who prefer the B path in the EG is 83.3\% for the pre-test and $100 \%$ of the post-test. In other words, each PSST in the EG gave the correct answer to the first part of this question. The second part of the question is the explanation of this answer. Here, there is a decrease in the percentage of correct answers given by the EG. The result, which was $33.3 \%$ of the pre-test, dropped to $22.2 \%$ in the post-test and to $5.5 \%$ on the permanence test.

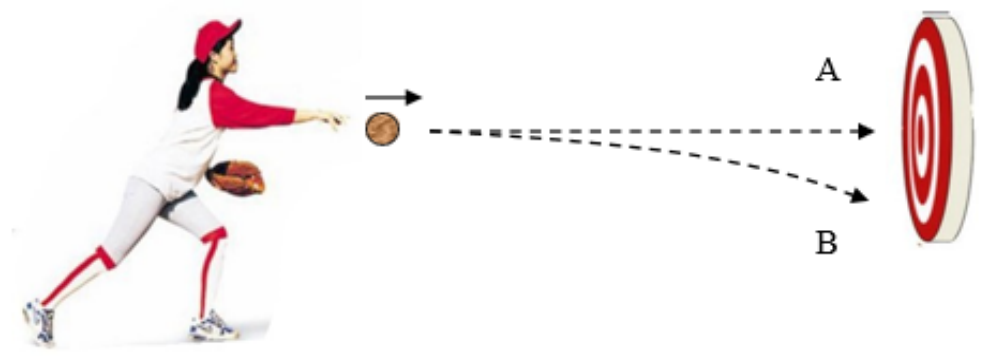

Figure 4. CQPM Q7: A girl throws the ball in a horizontal direction as shown in the figure.

Which path does the ball follow? Why? (Piten, et al., 2017)

This result supports the idea of Woods and Torley (1993), that even if the students remember the correct answer, they cannot remember the reason and they go back to their old "alternative concepts" while explaining the physical phenomenon.

However, the misconceptions detected in this study on the subject of the PM are consistent with previous studies in the literature and contribute to the literature (Appendix-2). Since there was no previous study in the field of Geogebra applications and conceptual change in science education, it was compared with the results of the study conducted by Computer Aided Teaching in this area of science.

In a study conducted by Dilber et al. (2009) with 82 students (43 in the EG and 39 in the CG), results in favor of the EG were obtained. The EG was taught using conceptual change activities and computer simulations. The CG took traditional physics course. Conceptual change text and simulations were used as conceptual change applications in the EG. Simulations were used to represent the physical concepts in the EG. These simulations were used by the teacher for demonstration purposes only to visualize the concepts of PM in the class. According to Dilber et al. (2009), simulations and associated learning goals provide at least one answer to frequently asked questions about the purpose of learning the subject for which simulations are used. As a result of their study, it is shown that the conceptual change in the EG students' misconceptions compared to the $\mathrm{CG}$ has a positive and higher average $(\mathrm{p}<.05$ and $\mathrm{t}=7.43$ ) (Dilber et al., 2009). In addition, computer simulations, which were used as an aid to conceptual change in Dilber et al. (2009) study, were used as a conceptual change tool to change the misconceptions PSST in this study. As can be seen from the results of this study, the simulations prepared with Geogebra applications will be effective in understanding the scientific reality behind the physical phenomenon in eliminating the misconceptions. As reported by Walsh (2017), a student can better 
understand and avoid misconceptions while creating physics simulations in GeoGebra while thinking about how to simulate a subject or phenomenon mathematically and graphically.

\section{Suggestions}

Teacher training programs should give PSST an opportunity to improve their knowledge of using technology for educational purposes. Additionally, in teacher training programs, courses suitable for conceptual change should be planned in the education process of PSST so that they do not convey their misconceptions to students. Teachers who are free from misconceptions will prepare a course by taking care of the students' misconceptions in their classes. 


\section{References:}

Bayraktar, S. (2009). Misconceptions of Turkish pre-service teachers about force and motion. International Journal of Science and Mathematics Education, 7(2), 273-291.

Büyüköztürk, Ş. (2012). Sosyal bilimler için veri analizi el kitabı. Ankara, Türkiye: Pegem Yayınc1lik.

Cho, H. H. (1985). An investigation of high school biology textbooks as sources of misconceptions and difficulties in genetics and some suggestions for teaching genetics. Science Education, 69(5), 707-19.

Clement, J. (1982). Students' preconceptions in introductory mechanics. American Journal of Physics, 50(1), 66-71.

Clement, J. (1983). A conceptual model discussed by Galileo and used intuitively by physics students. In D. Gentner, \& A. Stevens, Mental models (pp. 325-339). NJ : Hillsdale, Erlbaum.

Dekkers, P. J., \& Thijs, G. D. (1998). Making productive use of students' initial conceptions in developing the concept of force. Science education, 82(1), 31-51.

Dilber, R., Karaman, I., \& Duzgun, B. (2009). High school students' understanding of projectile motion concepts. Educational Research and Evaluation, 15(3), 203-222.

Driver, R., \& Erickson, G. (1983). Theories-in-action: Some theoretical and empirical issues in the study of students' conceptual frameworks in science. Studies in Science Education, 10(1), 37-60.

Driver, R., Asoko, H., Leach, J., Scott, P., \& Mortimer, E. (1994). Constructing scientific knowledge in the classroom, Educational researcher 23(7), 5-12.

Driver, R., Guesne, E., \& Tiberghien, A. (1985). Children's ideas and the learning of science. Children's ideas in science, 1-9.

Driver, R., Rushworth, P., Squires, A., \& Wood-Robinson, V. (1994). Making sense of secondary science: Research into children's ideas. R. Driver, P. Rushworth, A. Squires, \& V. Wood-Robinson (in), Making sense of secondary science: Research into children's ideas. London and New York: Routledge

Duit, R. (1993). Research on students' conceptions developments and trends. Third Misconceptions Seminar Proceedings (pp. 1-32). New York: Misconceptions Trust.

Duit, R., \& Treagust, D. F. (2003). Conceptual change A powerful framework for improving science teaching and learning. International journal of science education, 25(6), 671-688.

Duit, R., Goldberg, F. M., \& Niedderer, H. (1992). Research in Physics Learning: Theoretical Issues and Empirical Studies: . Proceedings of an International Workshop Held at the University of Bremen March 4-8, 1991 (Vol. 131). Bremen : IPN.

Erb, R., Wilhelm, T., \& Kuhn, J. (2015). Relativitätstheorie mit GeoGebra. Physik in unserer Zeit 46(3), 151-152.

Fosnot, C. T., \& Perry, R. S. (1996). Constructivism: A psychological theory of learning. In C. T. Fosnot, Constructivism: Theory, perspectives, and practice, 2nd Edition (pp. 8-33). New York and London: Teachers College Press, Columbia University.

Fox, R. (2001). Constructivism examined. Oxford review of education , 27(1), 23-35.

Fraenkel, J. R., Wallen, N. E., \& Hyun, H. H. (1993). How to design and evaluate research in education (Vol. 7). New York: McGraw-hill.

Gilbert, J. K., \& Watts, D. M. (1983). Concepts, misconceptions and alternative conceptions: Changing perspectives in science education. Studies in Science Education, 10(1), 61-98.

Gunstone, R. F., Gray, C., \& Searle, P. (1992). Some long-term effects of uninformed conceptual change. Science Education, 76(2), 175-197.

Halloun, I. A., \& Hestenes, D. (1985a). The initial knowledge state of college physics students. American journal of Physics, 53(11), 1043-1055.

Halloun, I. A., \& Hestenes, D. (1985b). Common sense concepts about motion. American Journal of Physics, 53(11), 1-18.

Hennessey, M. G. (1999). Probing the Dimensions of Metacognition: Implications for Conceptual Change Teaching-Learning. National Association for Research in Science Teaching (pp. 1-31). Boston: MA. 
Hewson, P. W. (1981). A conceptual change approach to learning science. European journal of science education, 3(4), 383-396.

Hofmann, J., Klar, P. J., \& von Aufschnaiter, C. (2012). Der große Wurf: Physik des Judos. Physik in unserer Zeit, 43(2), 78-83.

Hohenwarter, M., \& Preiner, J. (2007). Dynamic mathematics with GeoGebra. The Journal of Online Mathematics and its Applications, Volume 7. Article ID: 1448.

Jimoyiannis, A., \& Komis, V. (2001). Computer simulations in physics teaching and learning: a case study on students' understanding of trajectory motion. Computers \& education, 36(2), 183204.

Kerle, H. (2013 ). Mit GeoGebra Getriebelehre neu entdecken und besser verstehen. In 10. Kolloquium Getriebetechnik:. Technische Universität Ilmenau 11-13, 21-38.

Klammer, J. (1998). An Overview of Techniques for Identifying, Acknowledging and Overcoming Alternate Conceptions in Physics Education. Klingenstein Project Paper, Teacher College, Colombia University.

Klein, P., Gröber, S., Kuhn, J., \& Müller, A. (2014). Video analysis of projectile motion using tablet computers as experimental tools. Physics Education, 49(1), 37-40.

McCloskey, M. (1983a). Intuitive physics. Scientific American, 248(4), 114-122.

McCloskey, M. (1983b). Naive theories of motion . In D. Gentner, A. Stevens, \& D. a. Stevens (Ed.), Mental Models (pp. 299-324). Hillsdale, NJ: Lawrence Erlbaum Associates.

McCloskey, M., Caramazza, A., \& Green, B. (1980). Curvilinear motion in the absence of external forces: Naive beliefs about the motion of objects. Science , 210(4474), 1139-1141.

McDermott, L. C. (1984). Research on conceptual understanding in mechanics. Physics Today, 37(7), 24-32.

McDermott, L. C. (1991). Millikan Lecture 1990: What we teach and what is learned-Closing the gap. American journal of physics, 59(4), 301-315.

Millar, R. (1989). Constructive criticisms. International Journal of Science Education 11(5), 587596.

Minstrell, J. (1982). Explaining the' 'at rest' condition of an object. The physics teacher, 20(1), 1014.

Minstrell, J. (1984). Teaching for the development of understanding of ideas: Forces on moving objects. Observing Science Classrooms: Observing Science, 55-74.

Novak, J. D. (1987). Misconceptions and Educational Strategies in Science and Mathematics. Proceedings of the International Seminar (Volume III). New York: Ithaca.

Osborne, R., \& Freyberg, P. (1985). Learning in Science. The Implications of Children's Science. Portsmouth: Heinemann Educational Books.

Pallant, J. (2011). SPSS Survival Manual 6th edition: A step by step guide to data analysis using SPSS version 18. Maidenhead: Berkshire: Open University Press.

Piten, S., Rakkapao, S., \& Prasitpong, S. (2017). Cambodian students' prior knowledge of projectile motion. Journal of Physics: Conference Series (Vol. 901, No. 1) (p. 012116). IOP Publishing.

Posner, G. J., Strike, K. A., Hewson, P. W., \& Gertzog, W. A. (1982). Accommodation of a scientific conception: Toward a theory of conceptual change. Science education, 66(2), 211-227.

Prescott, A. E. (2004). Student understanding and learning about projectile motion in senior high school. Sydney: Unpublished Doctoral thesis, Macquarie University.

Prescott, A. E., \& Mitchelmore, M. (2005). Teaching Projectile Motion to Eliminate Misconceptions. In a. J. In H. L. Chick (Ed.), Proceedings of the 29th Conference of the International Group for the Psychology of Mathematics Education, 4 (pp. 97-104). Melbourne: PME.

Sadanand, N., \& Kess, J. (1990). Concepts in force and motion. The Physics Teacher, 28(8), 530533.

Rosenquist, M. L., \& McDermott, L. C. (1987). A conceptual approach to teaching kinematics. American Journal of Physics, 55(5), 407-415. 
Solvang, L., \& Haglund, J. (2018). GeoGebra in physics education. 10th International Conference on Education and New Learning Technologies 2-4 July, 2018 (pp. 9667-9674). Palma, Spain: IATED.

Tao, P. K. (1997). Confronting students' alternative conceptions in mechanics with the force and motion microworld. Computers in Physics, 11(2), 199-207.

Tao, P. K., \& Gunstone, R. F. (1999). The process of conceptual change in force and motion during computer-supported physics instruction. Journal of Research in Science Teaching, 36, 859-882.

Thijs, G. D. (1992). Evaluation of an Introductory Course on" Force" Considering Students' Preconceptions. Science Education, 76(2), 155-74.

Trowbridge, D. E., \& McDermott, L. C. (1980). Investigation of student understanding of the concept of velocity in one dimension. American journal of Physics, 48(12), 1020-1028.

Völker, S. (2015). Die Rolle der Beobachtung im Astronomie-Unterricht-Eine Schulbuchanalyse. PhyDid B-Didaktik der Physik-Beiträge zur DPG-Frühjahrstagung.

Walsh, T. (2017). Creating interactive physics simulations using the power of GeoGebra. The Physics Teacher, 55(5), 316-31.

Whitaker, J. R. (1983). Aristotle is not dead student understanding of trajectory motion. American Journal of Physics, 51 (4), 352-357.

Woods, R., \& Thorley, R. (1993). Understanding conceptual change teaching through case studies of students' learning. Third International Seminar on Misconceptions and Educational Strategies in Science and Mathematics. New York: Ithaca. 


\section{Appendixes}

Appendix-1 Misconceptions about projectile motion and the scientific equivalents of these errors.

\section{Misconception}

Scientific equivalent
Reference

(Bayraktar, 2008;

After losing contact with the cannon, there is no force acting the cannon ball, except the weight of the cannon ball.
Tao \& Gunstone, 1999;

Hestenes at al., 1992; Hallon

\& Hestenes, 1985b;

McCloskey,1983;

Whitaker,1983;Clement,1982)
The object moves in the direction of a force greater than its downward weight. At the

2 peak of the orbit followed by the object, this force is exhausted and the object starts to fall due to its weight.

3 moves upwards with a force greater than its weight.

An object that launches or rolls

4 in the horizontal direction of the cliff follows the reversed $\mathrm{L}$ path.

An object released from

5 constant horizontal velocity follows a linear path.

An object falls back from the

6 position where it was released with horizontal constant initial velocity.

7 No force is applied to an object released from a moving carrier.

Since an air resistance is applied

8 to an object released from a moving carrier, the object traces backwards.

From the same height, a released object falls before the object at a horizontal constant velocity because the released object takes a shorter path. Or the thrown object falls first because it has a greater velocity than the object released.

Objects that are released and thrown at the same height hit the ground at different times because the projectile has horizontal velocity, acceleration, or force.

The object moves under gravitational force in a parabolic orbit. Its horizontal velocity is constant, but its vertical velocity changes over time.
(Hallon \& Hestenes, 1985b; McCloskey, 1983; Whitaker, 1983; Clement, 1982)
The only force affecting the object is the gravitational force exerted by the ground.

An object thrown off a cliff moves at a constant horizontal velocity on a horizontal road and accelerates slowly downward.

For an observer on the ground, the (Hallon \& Hestenes, 1985b; orbit of the object will be parabolic. McCloskey,1983)

For an observer on the ground, the orbit of the object will be parabolic.

A force is applied by the gravitational field of the ground to an object making a horizontal PM.

The object follows a parabolic path forward.

(Hallon \& Hestenes, 1985; McCloskey, 1983)

(Hallon \& Hestenes, 1985; McCloskey, 1983)

(Hallon \& Hestenes, 1985; McCloskey, 1983) Hestenes, 1985b; McCloskey, 1983, Whitaker, 1983)

(Hallon \& Hestenes, 1985b; McCloskey, 1983)
(Clement, 1982; Hallon \&
An object that is released from the same height and the other thrown with a horizontal constant velocity hit to the ground simultaneously.
(Dilber et al., 2009;

Jimoyiannis \&

Komis, 2001;

Prescott \& Mitchelmore, 2005;

Whitaker; 1983)
The object that is released from the same height and thrown with a horizontal constant velocity falls to the ground simultaneously.
(Dilber et al., 2009; Whitaker, 1983) 
Students have confusion

11 between position and velocity, velocity and acceleration.
The displacement per unit time is called velocity, and the change in velocity per unit time is called acceleration.
(Bayraktar, 2008; Hestenes et al 1992; Hallon \& Hestenes, 198: Jimoyiannis \& Komis, 200 Whitaker,1983)

\section{Appendix-1 (continued)}

\begin{tabular}{|c|c|c|c|}
\hline & Misconception & Scientific equivalent & Reference \\
\hline 12 & $\begin{array}{l}\text { In an environment where air } \\
\text { resistance is neglected, objects } \\
\text { with different mass values hit } \\
\text { the ground at different times. }\end{array}$ & $\begin{array}{l}\text { Objects that are released to fall hit the } \\
\text { ground at the same time, because } \\
\text { when the air resistance is neglected, } \\
\text { only the force of gravity acts on the } \\
\text { objects. }\end{array}$ & (Dilber et al., 2009) \\
\hline 13 & $\begin{array}{l}\text { The final velocity of an object } \\
\text { which released to free fall } \\
\text { depends on the force of gravity. }\end{array}$ & \multirow{2}{*}{$\begin{array}{l}\text { The final velocity of objects released } \\
\text { to free fall depends on the height at } \\
\text { which the objects are released and the } \\
\text { gravitational acceleration. }\end{array}$} & (Dilber et al., 2009) \\
\hline 14 & $\begin{array}{l}\text { A ball with greater mass will } \\
\text { have a greater velocity when } \\
\text { released into free fall. }\end{array}$ & & (Jimoyiannis \& Komis, 2001) \\
\hline 15 & $\begin{array}{l}\text { The larger the mass, the greater } \\
\text { the acceleration in free fall. }\end{array}$ & \multirow{3}{*}{$\begin{array}{l}\text { The acceleration of free falling } \\
\text { objects is the gravitational } \\
\text { acceleration of the planet. }\end{array}$} & (Jimoyiannis \& Komis, 2001) \\
\hline 16 & $\begin{array}{l}\text { Since the higher of two balls of } \\
\text { different height has a greater } \\
\text { acceleration, when it hits the } \\
\text { ground, it has a greater velocity. }\end{array}$ & & (Jimoyiannis \& Komis, 2001) \\
\hline 17 & $\begin{array}{l}\text { The higher the ball of two balls } \\
\text { of different heights, the } \\
\text { acceleration is greater because it } \\
\text { moves more. }\end{array}$ & & (Jimoyiannis \& Komis, 2001) \\
\hline
\end{tabular}

Appendix-2 Summary of the misconceptions of pre-service science teachers revealed in this study

\begin{tabular}{|c|c|c|c|}
\hline Q Misconceptions & $\begin{array}{l}\text { Examples of Student } \\
\text { Answers }\end{array}$ & Scientific equivalents & References \\
\hline $\begin{array}{l}\text { The velocity vector } \\
\text { representing the } \\
\text { instantaneous } \\
\text { velocity follows the } \\
\text { orbit. }\end{array}$ & 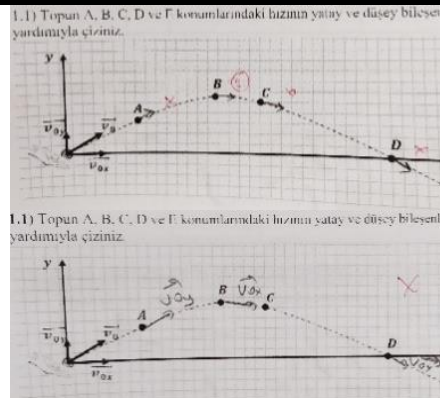 & $\begin{array}{l}\text { To present the } \\
\text { instantaneous velocity of } \\
\text { a projectile, a vector is a } \\
\text { line of contact with a } \\
\text { parabolic path at a } \\
\text { particular point. It } \\
\text { consists of two vectorial } \\
\text { components } \mathrm{Vx} \text { and } \mathrm{Vy} \text {. }\end{array}$ & $\begin{array}{l}\text { Piten, Rakkapao, \& } \\
\text { Prasitpong, } 2017\end{array}$ \\
\hline
\end{tabular}


The higher the position, the greater the velocity of an object (velocityposition confusion)

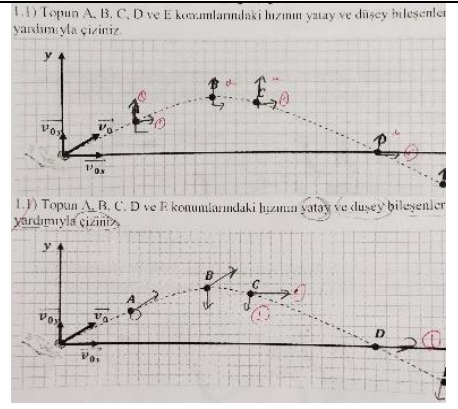

Instantaneous velocity is Hestenes et al., 1992 the rate of change in position over time.

\begin{tabular}{|c|c|c|c|}
\hline \multicolumn{4}{|l|}{ Appendix-2 (continued) } \\
\hline Q Misconceptions & $\begin{array}{l}\text { Examples of Student } \\
\text { Answers }\end{array}$ & Scientific equivalents & References \\
\hline $\begin{array}{l}\text { The components of } \\
\text { the horizontal } \\
\text { velocity } \mathrm{V} x \text { and the } \\
\text { vertical velocity } \mathrm{V} y \\
\text { of the projectile are } \\
\text { the same at every } \\
\text { point. }\end{array}$ & 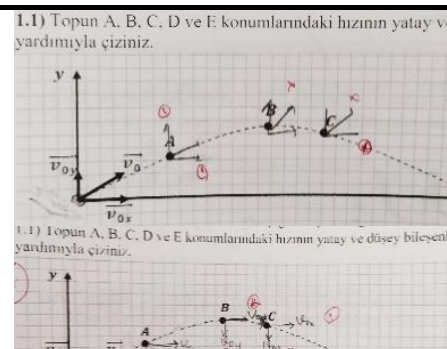 & $\begin{array}{l}\text { The horizontal velocity } \\
\mathrm{V} x \text { of the object is } \\
\text { constant. The vertical } \\
\text { velocity } \mathrm{V} y \text { varies as } \\
\text { much as the acceleration } \\
\text { of gravity over time. }\end{array}$ & \\
\hline $\begin{array}{l}\text { The velocity of the } \\
\text { object has a vertical } \\
\text { component at } \\
\text { maximum height. } \\
\text { (Point B) }\end{array}$ & $\int_{v_{0.0}}$ & $\begin{array}{l}\text { The velocity of the } \\
\text { object has no vertical } \\
\text { component at maximum } \\
\text { height. The horizontal } \\
\text { component is the same } \\
\text { as when it was first } \\
\text { thrown and does not } \\
\text { change during the } \\
\text { motion. }\end{array}$ & \\
\hline $\begin{array}{l}\text { When the object } \\
\text { reaches the level at } \\
\text { which it is thrown } \\
\text { horizontally, the } \\
\text { vertical component of } \\
\text { its velocity ends. } \\
\text { - }\end{array}$ & 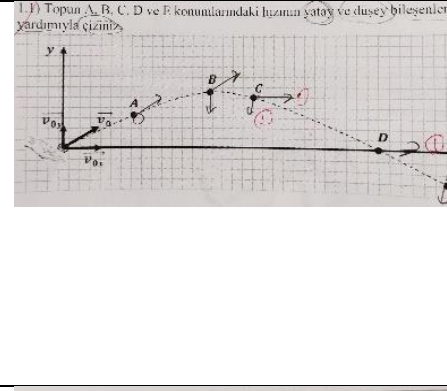 & $\begin{array}{l}\text { When the object reaches } \\
\text { the level at which it was } \\
\text { thrown horizontally, the } \\
\text { vertical component of its } \\
\text { velocity is in the } \\
\text { opposite direction of the } \\
\text { same magnitude as when } \\
\text { it was thrown. }\end{array}$ & \\
\hline $\begin{array}{l}\text { The direction of } \\
\text { acceleration follows } \\
\text { the direction of } \\
\text { motion. }\end{array}$ & 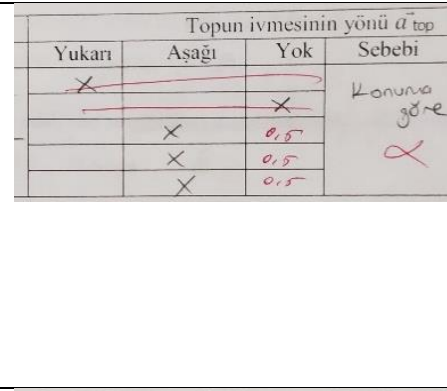 & $\begin{array}{l}\text { The direction of the } \\
\text { acceleration does not } \\
\text { change, since the object } \\
\text { moves with the } \\
\text { acceleration of gravity, } \\
\text { the acceleration of the } \\
\text { object is always towards } \\
\text { the center of the earth. }\end{array}$ & $\begin{array}{l}\text { Tao, 1997, Tao \& Gunstone, } \\
1999\end{array}$ \\
\hline $\begin{aligned} & \text { The magnitudes of } \\
& \text { acceleration and } \\
& \text { instantaneous } \\
& \text { - velocity are always } \\
& \text { the same parameter. }\end{aligned}$ & 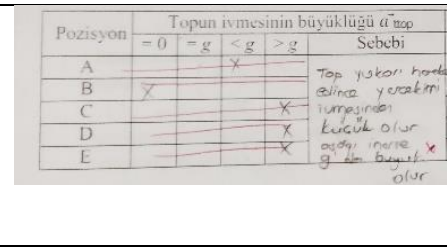 & $\begin{array}{l}\text { The magnitude of the } \\
\text { acceleration is the ratio } \\
\text { of the change in speed to } \\
\text { time. Acceleration for }\end{array}$ & $\begin{array}{l}\text { Rosequist \& McDermott, } \\
1987\end{array}$ \\
\hline
\end{tabular}


projectile motion is the

acceleration of gravity.

Acceleration

"instantly stops" at

the highest point of

the motion of the

object.

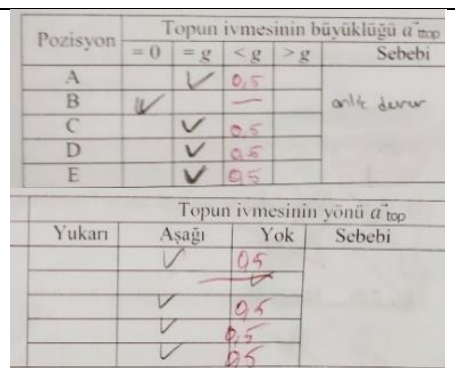

The direction and

magnitude of the

acceleration do not

change, the acceleration

of the object is always

towards the center

(down) of the earth, its

magnitude does not

change.

Appendix-2 (continued)

Q Misconceptions $\quad \begin{array}{llll}\text { Examples of Student Scientific equivalents } & \text { References }\end{array}$

\section{Answers}

The direction of the force vector follows the path of the object in the projectile motion.

After a hand force (or force thrown) loses contact with an object, it continues to affect the object.
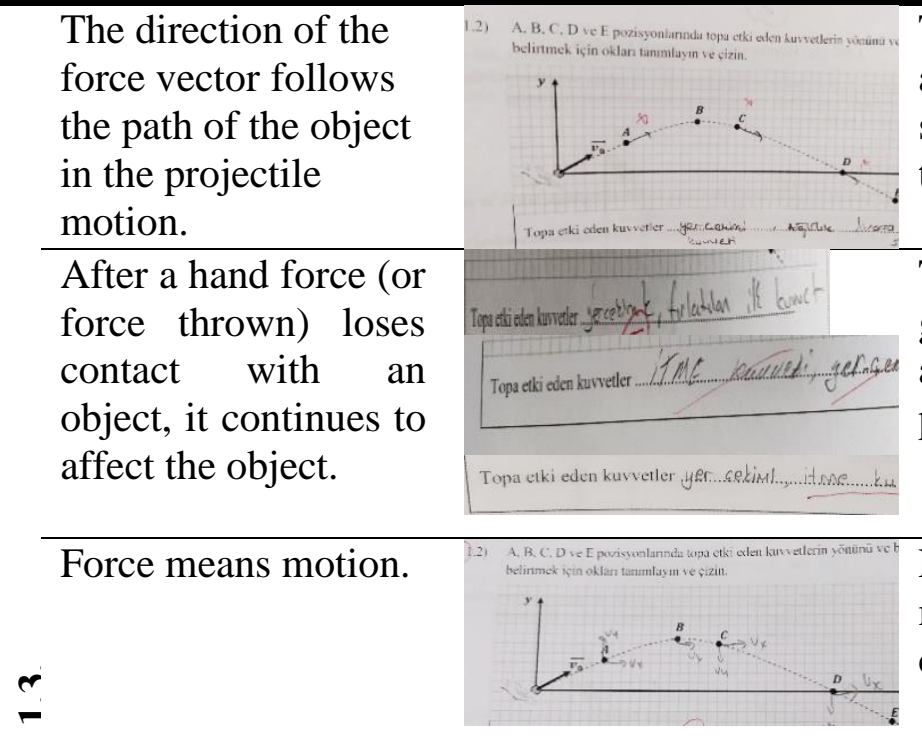

A body falling free from flat falling objects at the same height spends less time to reach the ground than an object moving in a curve.

At the same height, an object with initial horizontal velocity (faster) reaches the water in a shorter time to reach the ground than an object moving

- without initial

$\sim$ velocity.

From the same height, the velocity of the object released and launched into the water depends on the

$\sim$ type of movement

$\sim$ (straight or curved).

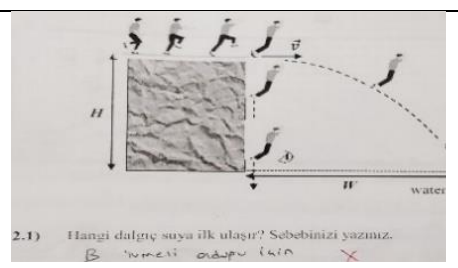

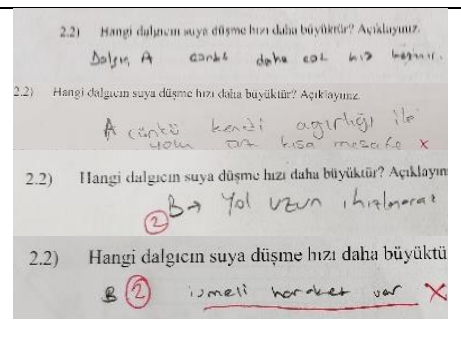

The direction of force and acceleration are the same, which is towards the center of the earth.

There is only the gravitational force affecting the object in the projectile motion.

Force, velocity and motion are different concepts.
McCloskey, 1983; Toa, 1997;

Toa \& Gunstone, 1999;

Prescott \& Michaelmore, 2005

Bayraktar, 2008;

Tao \& Gunstone, 1999; Tao, 1997; Hestenes at al., 1992; Hallon \& Hestenes, 1985b; McCloskey, 1983; Whitaker, 1983; Clement, 1982

Clement, 1982

Two objects, one Prescott \& Michaelmore, released for free fall and 2004 the other shot horizontally from the same height, reach the ground at the same time.

Two objects, one Prescott \& Michaelmore, released for free fall and 2005 the other shot horizontally from the same height, reach the ground at the same time.
The velocity of an object hitting water depends on the composition of its horizontal and vertical components. The vertical component of the velocities of both divers 
is the same. Since diver B

also has a horizontal

component, the velocity

of falling into water is

greater.

Appendix-2 (continued)

Q Misconceptions $\quad$ Examples of Student Scientific equivalents References

\section{Answers}

\begin{tabular}{|c|c|c|c|}
\hline $\begin{array}{l}\text { Objects that are } \\
\text { released and thrown } \\
\text { at the same height hit } \\
\text { the ground at different } \\
\text { times because the } \\
\text { object being thrown } \\
\text { has horizontal } \\
\text { er velocity, acceleration, } \\
\sim \text { or force. }\end{array}$ & 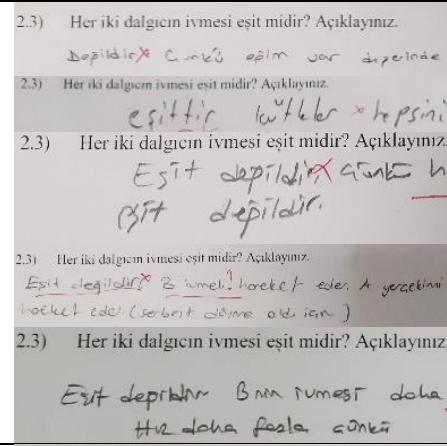 & $\begin{array}{l}\text { At the same height, } \\
\text { bodies that are released } \\
\text { and ejected have the } \\
\text { same acceleration } \\
\text { because the acceleration } \\
\text { of both bodies is the } \\
\text { acceleration of gravity. }\end{array}$ & $\begin{array}{l}\text { (Whitaker, 1983; } \\
\text { Dilber et al., 2009) }\end{array}$ \\
\hline $\begin{array}{l}\text { Since the acceleration } \\
\text { of two balls of } \\
\text { different height (if the } \\
\text { height increases for } \\
\text { this item) the higher } \\
\text { one has greater } \\
\nabla \text { velocity when it hits } \\
\text { the ground. }\end{array}$ & 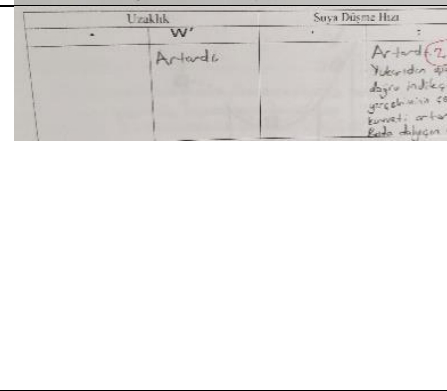 & $\begin{array}{l}\text { If the altitude is } \\
\text { increased, the velocity of } \\
\text { hitting the ground will } \\
\text { increase as the flight time } \\
\text { will increase. }\end{array}$ & $\begin{array}{l}\text { (Jimoyiannis \& } \\
\text { Komis, 2001) }\end{array}$ \\
\hline $\begin{array}{l}\text { The impulsive force } \\
\text { acting on the fired } \\
\text { ball more than the } \\
\text { weight causes it to } \\
\text { move in a straight } \\
\text { line, then the initial } \\
\text { impulse slowly } \\
\text { decreases, and the } \\
\text { downward } \\
\text { gravitational force } \\
\text { gradually moves over } \\
\text { the ball so that the net } \\
\text { force keeps the ball } \\
\text { moving in a curved } \\
\text { path. }\end{array}$ & 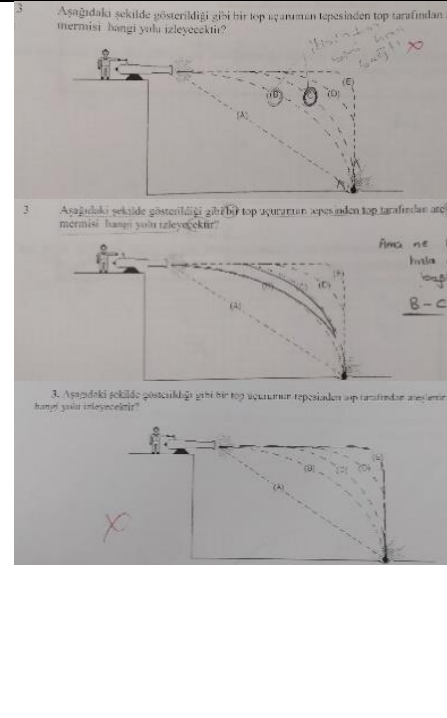 & $\begin{array}{l}\text { The fired shell moves in a } \\
\text { curved trajectory, this } \\
\text { trajectory is not } \\
\text { dependent on the initial } \\
\text { firing velocity, and only } \\
\text { gravitational force acts } \\
\text { on it. }\end{array}$ & $\begin{array}{l}\text { Whitaker, 1983; } \\
\text { McCloskey, 1983; } \\
\text { Halloun and } \\
\text { Hestenes, 1985; } \\
\text { Hestenes at al., } \\
\text { 1992; Prescott \& } \\
\text { Michaelmore, 2005 }\end{array}$ \\
\hline
\end{tabular}


Observed by a person on the ground, the object dropped from an airplane moving at a constant velocity will move backward and land behind the point where it was released, or an object released from a constant horizontal

- velocity follows a

$\nabla$ linear path.

Appendix-2 (continued)

\section{Q Misconceptions}

The object released from an airplane moving at a constant velocity will be observed by an observer on the plane that it will move backwards and land behind the release point.

Any object suspended
in air will remain in
air until made aware
of its situation.

The direction of acceleration indicates the lower position from the upper position.

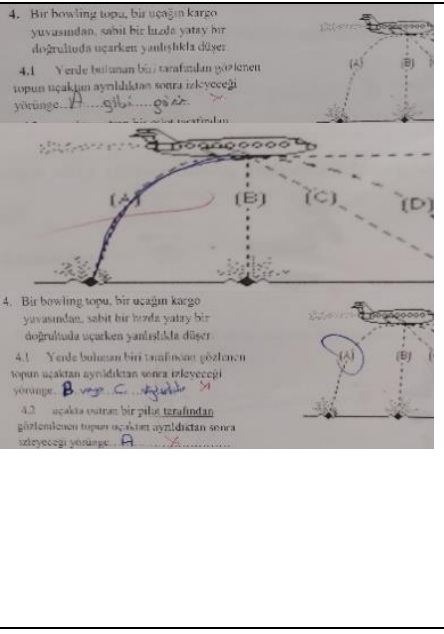

An object falling from a plane moving at a constant velocity is seen by a stationary observer on the ground, following a curved trajectory as in a projectile motion.
Hallon \& Hestenes, 1985;

McCloskey, 1983;
Whitaker, 1983

\section{Examples of Student Scientific equivalents References Answers}

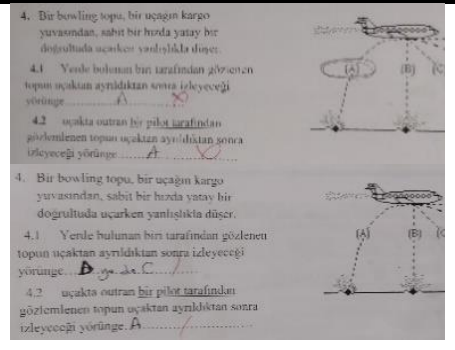

The object released from

a plane moving at a constant velocity will be observed by an observer on the plane as if it is moving linearly.

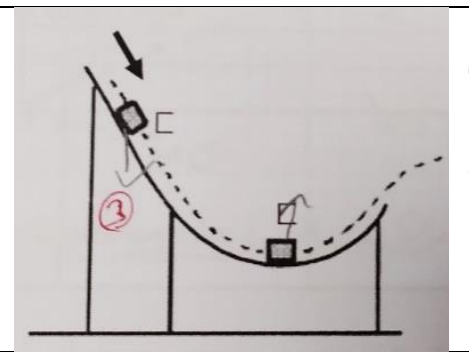

The direction of acceleration is the same as the direction of motion.

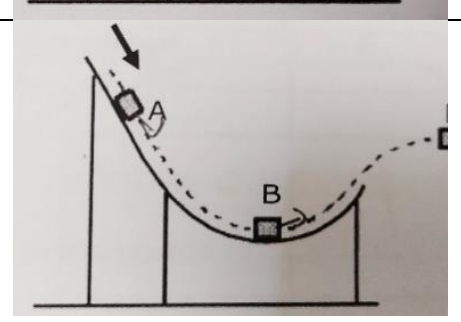

The object falling from McCloskey (1983), the plane moves in a curved orbit, which will be seen by a person on the plane in a linear direction.

Whitaker, 1983;

The direction of Hestenes et al., acceleration is towards 1992; the center of the earth.

The direction of the Tao, 1997, Tao \& Gunstone, acceleration does not 1999 change, since the object moves with the acceleration of gravity, the acceleration of the object is always towards the center of the earth. 


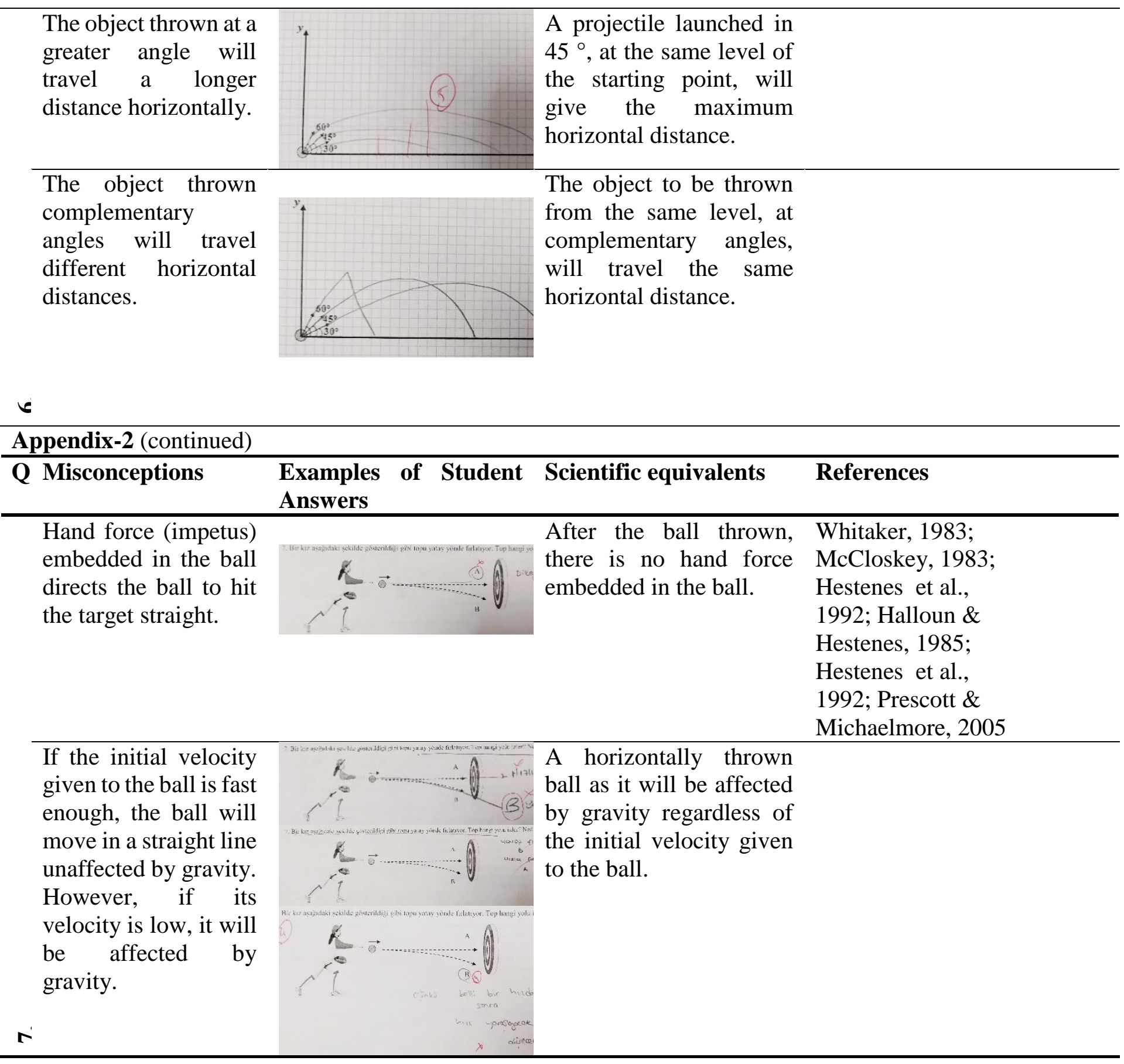

